\title{
Iodine-131 induces apoptosis in HTori-3 human thyrocyte cell line and G2/M phase arrest in a p53-independent pathway
}

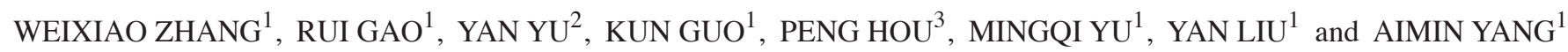 \\ ${ }^{1}$ Department of Nuclear Medicine, The First Affiliated Hospital of Xi'an Jiaotong University College of Medicine; \\ ${ }^{2}$ Department of Public Health, Xi'an Jiaotong University College of Medicine; ${ }^{3}$ Endocrinology Laboratory, \\ The First Affiliated Hospital of Xi'an Jiaotong University College of Medicine, Xi'an, Shaanxi 710061, P.R. China
}

Received February 13, 2014; Accepted November 7, 2014

DOI: $10.3892 / \mathrm{mmr} .2014 .3096$

\begin{abstract}
Iodine-131 is known to destroy residual thyroid tissue following surgical resection of differentiated thyroid carcinoma and is widely used to treat hyperthyroidism. However, the mechanism by which iodine-131 induces apoptosis and cell cycle arrest in the human thyrocyte cell line, Htori-3, remains to be elucidated. In the present study, the cytotoxic effect of iodine-131 on the HTori-3 cell line and the underlying mechanism of iodine-131-induced cell apoptosis were investigated. Cell viability was analyzed using an MTT assay, while cell apoptosis and cell cycle arrest were determined using flow cytometry. Reverse transcription-quantitative polymerase chain reaction (RT-qPCR) and western blot analyses were performed to determine the changes in the expression levels of p53, B-cell lymphoma 2 (Bcl-2), Fas and growth arrest and DNA damage-inducible 45 (GADD45), following iodine-131 treatment. The results demonstrated that iodine-131 may inhibit HTori-3 cell growth via cell apoptosis and G2/M phase arrest in a time- and dose-dependent manner. The iodine-131 dose required for $50 \%$ growth inhibition of HTori-3 cell viability $48 \mathrm{~h}$ after treatment was $27.75 \pm 2.22 \mathrm{MBq} / \mathrm{ml}$. Upregulation of Fas and downregulation of Bcl-2 expression levels were observed following iodine-131 treatment. The results of RT-qPCR revealed an increase in the GADD45 mRNA expression following HTori-3 cell exposure to iodine-131. Notably, the mRNA and protein expression levels of p53 were not altered following iodine-131 treatment. In conclusion, iodine-131 may induce apoptosis in HTori-3 cells by downregulating the expression of $\mathrm{Bcl}-2$ and upregulating the expression of Fas. In addition, iodine-131 may upregulate GADD45 mRNA expression in HTori-3 cells, resulting in $\mathrm{G} 2 / \mathrm{M}$ phase arrest in a $\mathrm{p} 53$-independent pathway.
\end{abstract}

Correspondence to: Professor Aimin Yang, Department of Nuclear Medicine, The First Affiliated Hospital of Xi'an Jiaotong University College of Medicine, 277 Yanta West Road, Xi'an, Shaanxi 710061, P.R. China

E-mail: yangaimin@mail.xjtu.edu.cn

Key words: iodine-131, apoptosis, G2/M phase arrest, p53

\section{Introduction}

Numerous radionuclides used in the diagnosis and therapy of disease are $\beta$ particle emitters $\left({ }^{153} \mathrm{Sm}\right.$-EDTMP, $\mathrm{Na}^{131} \mathrm{I}$, ${ }^{186} \mathrm{Re}-\mathrm{HEDP}$ and ${ }^{89} \mathrm{SrCl}$ ) and demonstrate promising therapeutic results. To date, a large number of preclinical and clinical studies have been performed on emitting radionuclides $(1,2)$. Iodine-131 is known to destroy residual thyroid tissue following surgical resection of differentiated thyroid carcinoma (3) and is widely used to treat hyperthyroidism (4). In addition, iodine-131 has been conjugated to antibody derivatives and used to treat other malignant diseases by radioimmunotherapy (RIT). Cell death induced by RIT has been demonstrated to trigger the apoptosis of tumor cells (5). The cytotoxic effect of iodine-131 on the thyroid cancer cell line, BCPAP, has been investigated and low iodine-131 doses have been found to result in cell apoptosis (6). However, the mechanism through which iodine-131 induces cell death in the thyrocyte cell line, HTori-3, remains to be fully elucidated.

Radiation-induced DNA damage promotes the expression of the p53 gene at the post-translational level (7). Activation of p53 leads to cell growth arrest at G1 and/or G2 phase, DNA repair, senescence or apoptosis $(8,9)$. The B-cell lymphoma 2 (Bcl-2) family is divided into proapoptotic proteins, including Bcl-2 associated $\mathrm{X}$ protein (Bax), and antiapoptotic proteins, including Bcl-2 (10). Whether a cell undergoes apoptosis depends, to a certain extent, on the ratio of Bcl-2 to Bax (11). The cell-surface receptor, Fas [also known as CD95 or apoptosis antigen-1 (Apo-1)], is a key component of the extrinsic death pathway and is activated through the binding of its ligand, FasL (12). Radiation-induced cell cycle arrest at the G1 and G2 restriction points allows cells to repair DNA damage prior to DNA synthesis and cell division $(13,14)$.

A number of thyroid cancer cell lines have been demonstrated to lose the expression of thyroid-specific genes and have altered karyotypes, including inactivation of the tumor suppressor gene, p53 (15). HTori-3 cell line is a nontumorigenic, immortalized human thyrocyte cell line and preserves the most specialized functions of differentiated thyroid cells (16). In the present study, the HTori-3 cell line was used as a model and the cytotoxic effect of iodine-131 on the human thyrocyte cell line, HTori-3, was investigated. In addition, the possible 
underlying mechanisms of iodine-131-induced cell apoptosis, cell cycle arrest and the effect of iodine-131 therapy in hyperthyroidism were assessed, including the p53 pathway.

\section{Materials and methods}

Cell culture. The HTori-3 cell line was provided by Professor Peng Hou (Endocrinology Laboratory, The First Affiliated Hospital of Xi'an Jiaotong University College of Medicine, Xi'an, China). The cells were cultured in RMPI-1640 medium (Hyclone, Logan, UT, USA) and supplemented with $10 \%$ heat-inactivated fetal bovine serum (Minhai, Lanzhou, China) and $1 \%$ penicillin/streptomycin (Hyclone) in a $5 \% \mathrm{CO}_{2}$ humidified atmosphere at $37^{\circ} \mathrm{C}$. The study was approved by the ethics committee of the First Affiliated Hospital of Xi'an Jiaotong University, Xi'an, China.

Iodine-131 uptake assay. The cells were seeded at $1 \times 10^{5} /$ well in 6-well plates for $24 \mathrm{~h}$. Subsequently, the cells were cultured for $24 \mathrm{~h}$ with $2 \mathrm{ml}$ culture medium per well containing 14.8 $\mathrm{MBq} / \mathrm{ml}$ iodine-131. Next, the iodine-131-containing medium was decanted, and the cells were washed twice with phosphate-buffered saline (PBS) and trypsinized (Hyclone) to count the total cell number. The radioactivity of the cells was measured with a radioactivity counter (Sim-max LSA3000; Sim-max Technology Co., Ltd, Shanghai, China).

Cell viability assay. Cell viability was determined using an MTT assay [3-(4,5-dimethylthiazol-2-yl)-2,5-diphenyltetrazolium bromide; MP Biomedicals, Santa Ana, CA, USA]. The cells were seeded at $1.5 \times 10^{4} / \mathrm{ml}$ in 96 -well plates for $24 \mathrm{~h}$. Subsequently, iodine-131 was added to achieve final iodine-131 activity concentrations of 7.4, 14.8 and $29.6 \mathrm{MBq} / \mathrm{ml}$. Next, the cells were exposed to iodine-131 treatment for $12,24,48$, 72 and $96 \mathrm{~h}$ with six replicates for each concentration value, while identical volumes of PBS were added to the control wells. Following addition of $40 \mu \mathrm{l} /$ well MTT, the samples were incubated for a further $4 \mathrm{~h}$. The medium was discarded and the formazan crystals were solubilized in $150 \mu \mathrm{l}$ /well DMSO. The sample absorbance at $570 \mathrm{~nm} / 630 \mathrm{~nm}$ was measured using a Multiskan plate reader (BioTek Instruments, Inc., Winooski, VT, USA). The absorbance was directly associated with the viable cell number. The experiment was performed at least in triplicate.

Cell apoptosis assay. A cell apoptosis assay was performed using an Annexin-V-fluorescein isothiocyanate (FLOUS) staining kit (Roche Diagnostics GmbH, Mannheim, Germany). The cells were seeded at $5 \times 10^{4} / \mathrm{ml}$ in 6 -well plates for $24 \mathrm{~h}$ and then treated with various doses of iodine-131 (7.4, 14.8 or $22.2 \mathrm{MBq} / \mathrm{ml}$ ) (2) for $48 \mathrm{~h}$ or $14.8 \mathrm{MBq} / \mathrm{ml}$ iodine- 131 for different time periods $(24,48$ or $72 \mathrm{~h})$. A dose of $14.8 \mathrm{MBq} / \mathrm{ml}$ iodine-131 was selected for evaluation over various time-points following preliminary experiments which revealed low apoptotic levels with a dose of $7.4 \mathrm{MBq} / \mathrm{ml}$ and almost total apoptosis with a dose of $22.2 \mathrm{MBq} / \mathrm{ml}$. At the designated time-points, the medium and the trypsinized cells were collected in a centrifuge tube. Subsequently, the cells were washed with PBS and centrifuged at $200 \mathrm{x}$ g for $5 \mathrm{~min}$. Finally, the cells were resuspended in $100 \mu \mathrm{l}$ of Annexin-V-FLOUS labeling solution and analyzed by flow cytometry (BD Biosciences, San Jose, CA, USA).

Cell cycle assay. The cells were seeded at $1 \times 10^{5} /$ well in 6-well plates for $24 \mathrm{~h}$ and then exposed to various iodine-131 doses $(7.4,14.8$ or $22.2 \mathrm{MBq} / \mathrm{ml})$ for a further $24 \mathrm{~h}$ or the same dose $(14.8 \mathrm{MBq} / \mathrm{ml})$ for different time periods $(12,24$ and $48 \mathrm{~h}$ ). At the various time points, the cells were trypsinized and fixed in ice-cold $70 \%$ ethanol, followed by storing at $4^{\circ} \mathrm{C}$ overnight. Following centrifugation at $1,000 \mathrm{rpm}$ for $5 \mathrm{~min}$, the samples were resuspended in a solution containing $50 \mathrm{~g} / \mathrm{ml}$ propidium iodide (MP Biomedicals) and $100 \mathrm{U} / \mathrm{ml}$ RNase (MP Biomedicals). The DNA content of the nuclei was measured using flow cytometry (BD Biosciences), counting 15,000 gated events.

Western blot analysis. HTori-3 cells were treated with $14.8 \mathrm{MBq} / \mathrm{ml}$ iodine-131 for different time periods (12, 24 and $48 \mathrm{~h}$ ). At the indicated times following irradiation, total protein was extracted using the radioimmunoprecipitation assay buffer (Wolsen, Xi'an, China). Total protein $(\sim 150 \mu \mathrm{g})$ was denatured in loading buffer at $100^{\circ} \mathrm{C}$ for $10 \mathrm{~min}$ and electrophoresed using $10 \%$ sodium dodecyl sulfate-polyacrylamide gel electrophoresis (SDS-PAGE). Lysates containing $150 \mu \mathrm{g}$ proteins were subjected to SDS-PAGE, followed by transfer of proteins to a polyvinylidene difluoride membrane (EMD Millipore, Billerica, MA, USA). The membranes were blocked with 5\% bovine serum albumin (MP Biomedicals LLC, Santa Ana, CA, USA) for $1 \mathrm{~h}$ at room temperature and incubated overnight at $4^{\circ} \mathrm{C}$ with the primary rabbit anti-human $\mathrm{p} 53$, mouse anti-human Bcl-2 and mouse anti-human Fas monoclonal antibodies (1:1,000; Epitomics, Burlingame, CA, USA). Subsequently, the membranes were washed with Tris-buffered saline containing $0.1 \%$ Tween-20 for 20-30 min, followed by incubation with the secondary antibody (1:20). The secondary antibodies used were horseradish peroxidase-labeled anti-rabbit or -mouse immunoglobulin (Ig)G (Santa Cruz Biotechnology, Heidelberg, Germany). Membranes reprobed with mouse anti-GAPDH (Abmart, Arlington, MA, USA) were used as the internal control for equal protein loading.

$R N A$ isolation and reverse transcription-quantitative polymerase chain reaction ( $R T-q P C R)$. The RNA was extracted from cells with TRIzol reagent (Takara Biotechnology Co., Ltd., Dalian, China) according to the manufacturer's instructions. The concentration of total RNA was determined using a spectrophotometer (BioTek Instruments, Inc., Winooski, VT, USA) and the 260/280 absorbance ratio, used to investigate the sample purity, was between 1.8 and 2.0. cDNA synthesis was performed using $500 \mathrm{ng}$ total RNA in a reaction volume of $10 \mu 1$. The thermal cycling conditions were as follows: $15 \mathrm{~min}$ at $37^{\circ} \mathrm{C}$ and $5 \mathrm{sec}$ at $85^{\circ} \mathrm{C}$. Copy number quantification was performed with RT-qPCR using $\beta$-actin as the internal reference. The primer sequences of $\mathrm{p} 53, \mathrm{Bcl}-2$, Fas, growth arrest and DNA damage-inducible 45 (GADD45) and $\beta$-actin are shown in Table I. Following reverse transcription, the conditions were as follows: $95^{\circ} \mathrm{C}$ for $2 \mathrm{~min}, 40$ cycles of $15 \mathrm{sec}$ at $95^{\circ} \mathrm{C}$ and $60 \mathrm{sec}$ at $60^{\circ} \mathrm{C}$ for annealing and extension were run on a CFX96 Thermal Cycler Dice ${ }^{\mathrm{TM}}$ real-time PCR system (Bio-Rad Laboroatories, Inc., Hercules, CA, USA). 
Table I. Primers sequences of p53, Bcl-2, Fas, GADD45 and $\beta$-actin.

\begin{tabular}{lllc}
\hline Gene & \multicolumn{1}{c}{ Forward } & \multicolumn{1}{c}{ Reverse } & Length (bp) \\
\hline p53 & CTCCTCAGCATCTTACCGAGT & GCTGTTCCGTCCCAGTAGATTA & 239 \\
Bcl-2 & ATGTGTTGGAGAGCGTCAAC & AGAGACAGCCAGGAGAAATCAAAC & 182 \\
Fas & TGGCTTTGTCTTCTTCTTTGC & CTTGGTTTCCTTTCTGTGCTT & 97 \\
GADD45 & CCCAGTGGACAGCGAGCCAGC & ACTGCAGGCTTCCTGTGGGC & 137 \\
$\beta$-actin & CTGGGACATGGAGAAA & AAGGAAGGAAGAGTGC & 285 \\
\hline
\end{tabular}

Bcl-2, B-cell lymphoma 2; GADD45, growth arrest and DNA damage-inducible 45.

The RT-qPCR reaction was conducted with $100 \mathrm{ng}$ cDNA in a $20 \mu \mathrm{l}$ reaction volume containing $10 \mu \mathrm{l} \mathrm{SYBR}{ }^{\circledR}$ Premix Ex Taq $^{\mathrm{TM}}$ II (Takara Biotechnology Co., Ltd.), $0.4 \mu \mathrm{M}$ forward

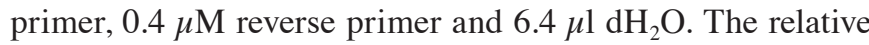
representation of the target gene copy number in the irradiated cells with respect to the non-irradiated control was obtained using the formula $2^{-\Delta \Delta \mathrm{Ct}}$, which is a simplified calculation tool derived from the $\Delta \Delta \mathrm{Ct}$ method for gene expression analysis. Each sample was analyzed twice and the mean values were calculated for statistical analysis.

Statistical analysis. Data are presented as the mean \pm standard deviation. Statistical analyses were performed using SPSS 16.0 statistical software for Windows (SPSS, Inc., Chicago, IL, USA). The statistical significance of differences between the groups were investigated using Student's unpaired t-test. $\mathrm{P}<0.05$ was considered to indicate a statistically significant difference.

\section{Results}

Human thyrocyte HTori-3 cells exhibit iodine uptake activity. To determine whether the HTori-3 cells possessed iodine uptake activity, the iodine uptake was assessed with or without iodine-131 treatment. Following treatment with $14.8 \mathrm{MBq} / \mathrm{ml}$ iodine-131 for $24 \mathrm{~h}$, the radioactivity count was found to be $51128 \pm 6.02 \mathrm{cpm}$, while the radioactivity in the control group was $366.5 \pm 4.13 \mathrm{cpm}$, indicating that HTori-3 cells possessed iodine uptake activity.

Iodine-131 inhibits cell growth in a time- and dose-dependent manner. In order to investigate the effect of iodine-131 on human thyrocyte cells, HTori-3 cells were incubated with various concentrations of iodine-131 $(7.4,14.8$ or $29.6 \mathrm{MBq} / \mathrm{ml})$ for designated time periods $(12,24,48,72$ and $96 \mathrm{~h})$ and the cell viability was determined using an MTT assay. The results (Fig. 1) revealed that iodine-131 produced a significant inhibition of cell growth compared with the control group. Notably, $15.7 \%$ inhibition of cell growth was observed at a dose of $7.4 \mathrm{MBq} / \mathrm{ml}(\mathrm{P}<0.01)$ and $49.5 \%$ inhibition was observed at a dose of $29.6 \mathrm{MBq} / \mathrm{ml}(\mathrm{P}<0.01)$ after $48 \mathrm{~h}$. Furthermore, treatment with $14.8 \mathrm{MBq} / \mathrm{ml}$ iodine-131 induced a significant reduction in cell viability (34.8\%) after $48 \mathrm{~h}$ $(\mathrm{P}<0.01)$, which was maintained to $93.2 \%$ after $96 \mathrm{~h}(\mathrm{P}<0.01)$. The experiments revealed that iodine-131 exerted a cytotoxic effect on the human thyrocyte cell line. Growth inhibition was induced in a time- and dose-dependent manner. The iodine-131

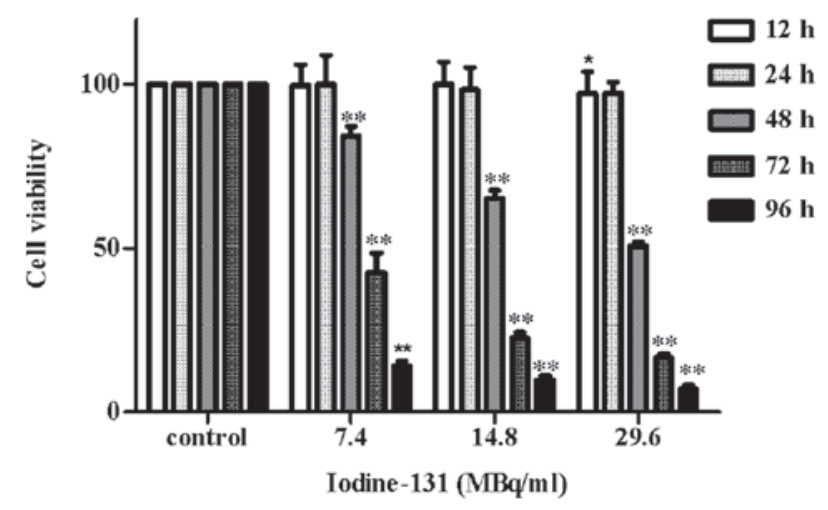

Figure 1. Effect of iodine-131 on cell viability of HTori-3 cells, which were treated with various doses of iodine-131 $(7.4,14.8$ and $29.6 \mathrm{MBq} / \mathrm{ml})$ for 12 , $24,48,72$ or 96 h. Cell viability was determined by MTT assay. The data are presented as the mean \pm standard deviation of three independent experiments. ${ }^{*} \mathrm{P}<0.05$ and ${ }^{* *} \mathrm{P}<0.01$ versus the control group.

dose required for $50 \%$ growth inhibition of HTori-3 cells after $48 \mathrm{~h}$ was $27.75 \pm 2.22 \mathrm{MBq} / \mathrm{ml}$.

Iodine-131 induces growth inhibition of HTori-3 cells via cell cycle arrest and apoptosis. To determine whether iodine-131 affected the HTori-3 cell apoptotic response, HTori-3 cells were treated with different doses of iodine-131 $(7.4,14.8$ or 22.2 $\mathrm{MBq} / \mathrm{ml}$ ) for $48 \mathrm{~h}$ or with $14.8 \mathrm{MBq} / \mathrm{ml}$ iodine-131 for various time periods (24, 48 or $72 \mathrm{~h})$. Apoptosis was analyzed using flow cytometry. The negative control was treated with PBS. Apoptosis was observed in the HTori-3 cells upon iodine-131 administration in a time- and dose-dependent manner. The apoptotic cell percentage $48 \mathrm{~h}$ after iodine-131 treatment was $20.3 \%$ at $7.4 \mathrm{MBq} / \mathrm{ml}, 35.4 \%$ at $14.8 \mathrm{MBq} / \mathrm{ml}(\mathrm{P}<0.01)$ and $53.6 \%$ at $22.2 \mathrm{MBq} / \mathrm{ml}(\mathrm{P}<0.05)$, while only $5.8 \%$ cell death via apoptosis was observed in the control group (Fig. 2A). Evident apoptosis was induced at $48 \mathrm{~h}$ after treatment with $14.8 \mathrm{MBq} / \mathrm{ml}$ iodine-131 (39.9\%; $\mathrm{P}<0.01)$, while a higher number of apoptotic cells was observed at $72 \mathrm{~h}(50.6 \%$; $\mathrm{P}<0.01$; Fig. $2 \mathrm{~B})$.

The capacity of iodine-131 to inhibit cell cycle progression was evaluated via flow cytometry. A representative example depicting the effect of iodine-131 treatment on cell cycle phase distribution in the HTori-3 cell line is shown in Fig. 3. At 24 after iodine-131 treatment, the percentages of cells in the $\mathrm{G} 2 / \mathrm{M}$ phase were $24.4 \%$ at $7.4 \mathrm{MBq} / \mathrm{ml}(\mathrm{P}<0.05), 38.6 \%$ at $14.8 \mathrm{MBq} / \mathrm{ml}(\mathrm{P}<0.01)$ and $72.4 \%$ at $22.2 \mathrm{MBq} / \mathrm{ml}(\mathrm{P}<0.05)$, while the percentage of the control group was $13.5 \%$. 

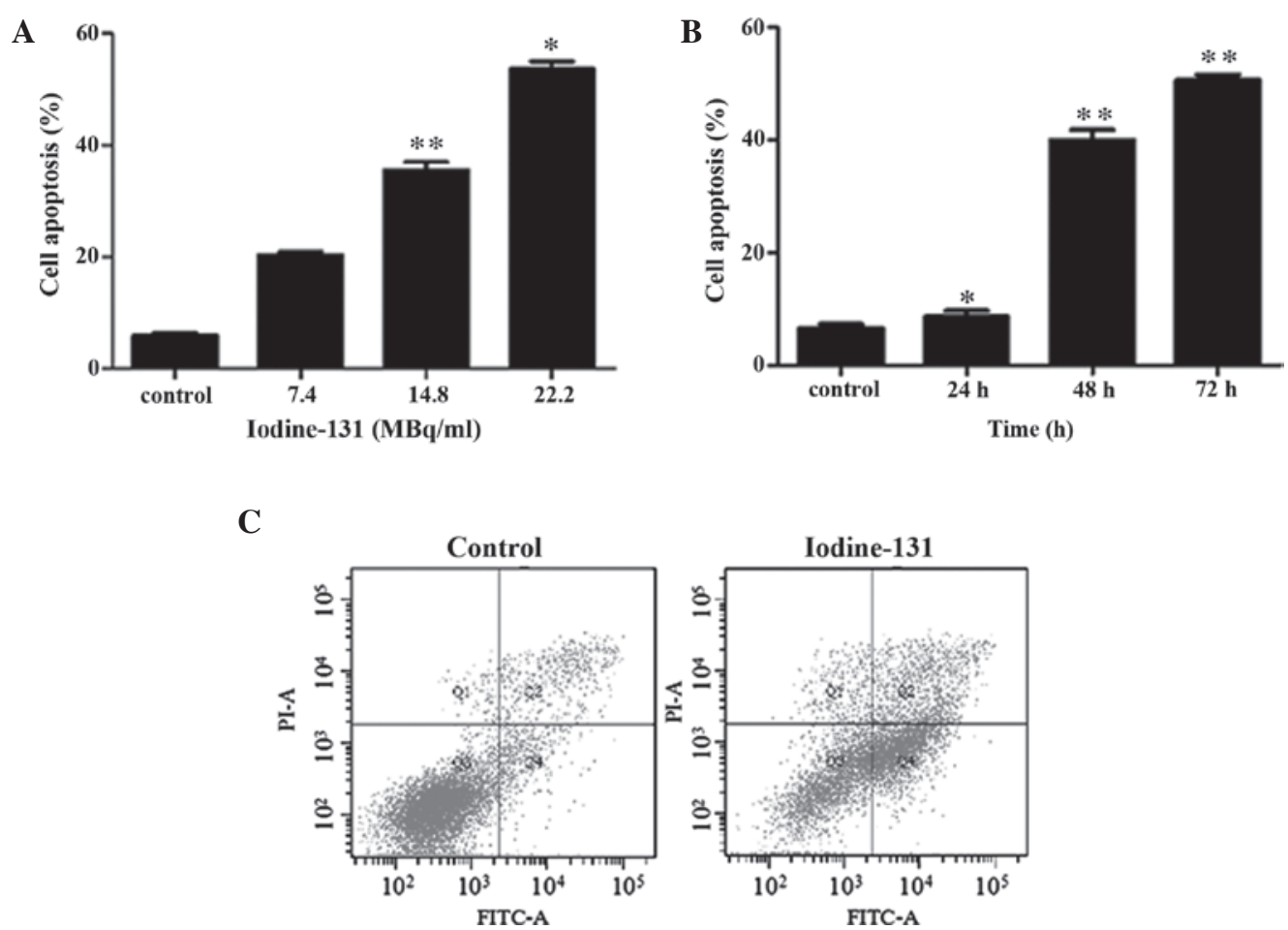

Figure 2. Iodine-131 induces apoptosis. HTori-3 cells were treated with (A) various concentrations of radioactive iodine-131 (7.4, 14.8 and $22.2 \mathrm{MBq} / \mathrm{ml})$ for $48 \mathrm{~h}$, or (B) $14.8 \mathrm{MBq} / \mathrm{ml}$ iodine- 131 for 24,48 or $72 \mathrm{~h}$. (C) Cell apoptosis was determined by flow cytometry. The data are presented as the mean \pm standard deviation of three independent experiments. ${ }^{*} \mathrm{P}<0.05$ and ${ }^{* *} \mathrm{P}<0.01$, vs. control group. PI, propidium iodide; FITC, fluorescein isothiocyanate.
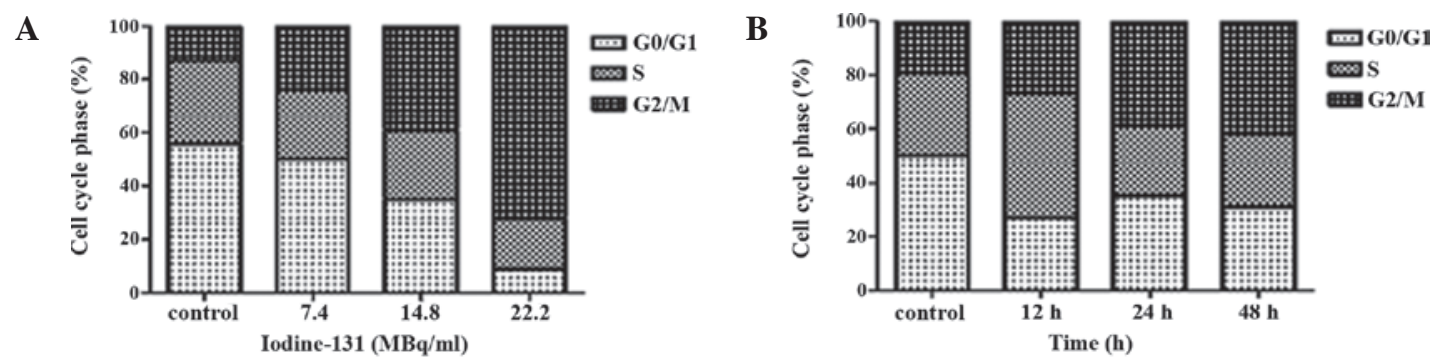

C

Control

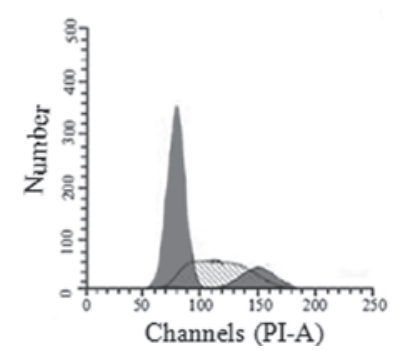

Iodine-131

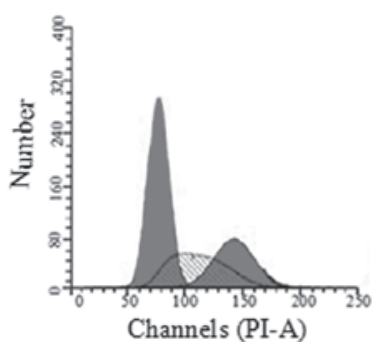

Figure 3. Iodine-131 induces accumulation of cells in G2/M. HTori-3 cells were harvested following exposure to (A) different concentrations of iodine-131 (7.4, 14.8 and $22.2 \mathrm{MBq} / \mathrm{ml}$ ) for $24 \mathrm{~h}$, or (B) (B) $14.8 \mathrm{MBq} / \mathrm{ml}$ iodine-131 for 12, 24 or $48 \mathrm{~h}$. (C) The cells were fixed and stained with PI for flow cytometry. The data are presented as the mean \pm standard deviation of three independent experiments. PI, propidium iodide.

Treatment with $14.8 \mathrm{MBq} / \mathrm{ml}$ iodine- 131 for $24 \mathrm{~h}$ resulted in an accumulation of $39.2 \%$ cells in the $\mathrm{G} 2 / \mathrm{M}$ phase compared with the control (19.1\%; $\mathrm{P}<0.01)$. The $\mathrm{G} 2 / \mathrm{M}$ accumulation was more pronounced in cells treated with iodine-131 for $48 \mathrm{~h}(42.3 \%$; $\mathrm{P}<0.01)$.

Mitochondrial and death receptor pathways are involved in iodine-131-induced apoptosis. To assess the effect of iodine-131 treatment on the expression of apoptosis-associated genes in HTori-3 cells, the expression levels of Bcl-2 and Fas were determined using western blot analysis and RT-qPCR. Fas was found to be transcriptionally increased, while Bcl-2 mRNA expression decreased following iodine-131 treatment (Figs. 4A and B), determined by RT-qPCR. The increased Fas and decreased $\mathrm{Bcl}-2$ expression levels, following treatment with iodine-131, were also observed by western blot analysis (Fig. 4C) . 
A

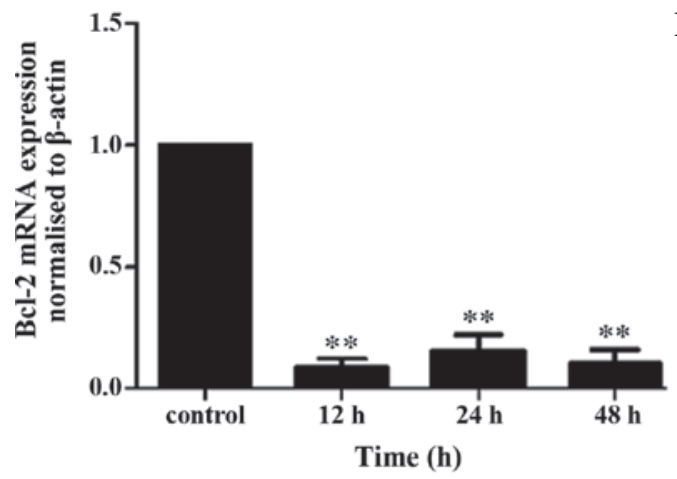

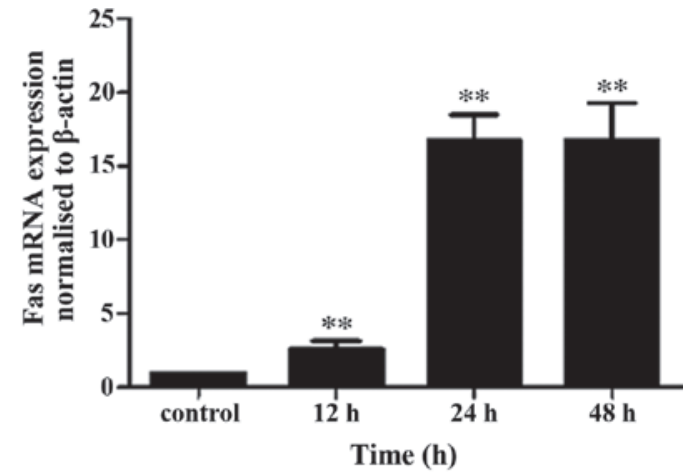

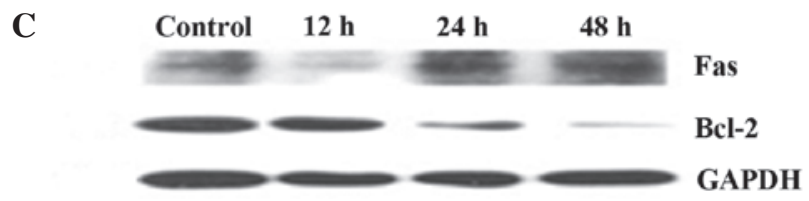

Figure 4. Activation of apoptotic molecules following iodine-131 treatment. HTori-3 cells were treated with $14.8 \mathrm{MBq} / \mathrm{ml}$ iodine-131 for 12,24 or $48 \mathrm{~h}$ and the mRNA expression levels of (A) Bcl-2 and (B) Fas were determined by reverse transcription-quantitative polymerase chain reaction. (C) HTori-3 cells were treated with $14.8 \mathrm{MBq} / \mathrm{ml}$ iodine-131 for 12,24 or $48 \mathrm{~h}$ and the protein expression levels of Bcl-2 and Fas were determined by western blot analysis. The data are presented as the mean \pm standard deviation of three independent experiments. ${ }^{*} \mathrm{P}<0.05$ and ${ }^{* *} \mathrm{P}<0.01$, vs. control group. Bcl-2, B-cell lymphoma 2 .

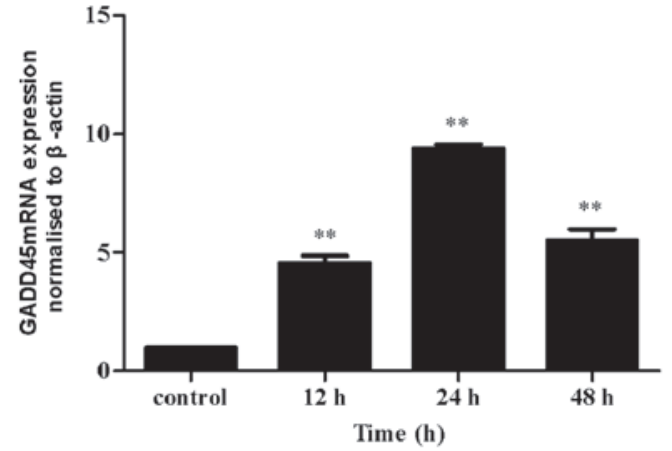

Figure 5. GADD45 mRNA accumulation following radioactive iodine-131 treatment. HTori-3 cells were treated with $14.8 \mathrm{MBq} / \mathrm{ml}$ iodine-131 for 12 , 24 or $48 \mathrm{~h}$. The mRNA expression of GADD45 was determined by reverse transcription-quantitative polymerase chain reaction. The data are presented as the mean \pm standard deviation of three independent experiments. ${ }^{*} \mathrm{P}<0.05$ and ${ }^{* *} \mathrm{P}<0.01$, vs. control group. GADD45, growth arrest and DNA damage-inducible 45 .

Iodine-131 induces GADD45 accumulation in HTori-3 cells. To further examine whether the G2 phase arrest induced by iodine-131 was correlated with GADD45 in the thyroid cell line, the expression of GADD45 was evaluated by RT-qPCR prior to and following iodine-131 exposure. A statistically significant increase was observed in GADD45 transcription compared with the control (Fig. 5).

Iodine-131 results in HTori-3 cell growth inhibition in a p53-independent manner. To investigate whether p53 was involved in the iodine-131-induced inhibition of HTori-3 cell growth, mRNA and protein expression levels of p53 were determined following cellular stress induced by iodine-131. No changes were observed in p53 mRNA expression following exposure to iodine-131 (Fig. 6A). In addition, iodine-131 did not affect $\mathrm{p} 53$ protein expression, and even presented a
A

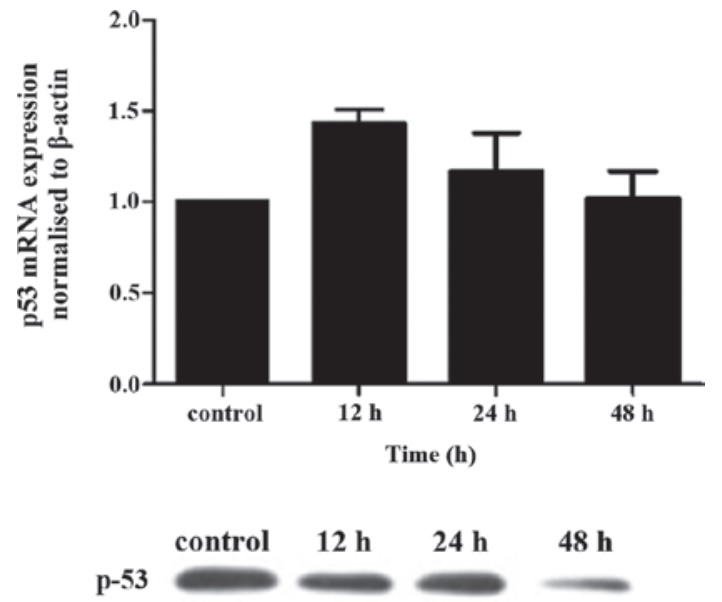

GAPDH

Figure 6. Iodine-131 treatment results in growth inhibition of HTori-3 cells in a p53-independent pathway. HTori-3 cells were treated with $14.8 \mathrm{MBq} / \mathrm{ml}$ iodine-131 for 12, 24 or $48 \mathrm{~h}$. (A) The mRNA expression of p53 was determined by reverse transcription-quantitative polymerase chain reaction. (B) The protein expression of p53 was determined by western blot analysis. The data are presented as the mean \pm standard deviation of three independent experiments.

reducing tendency on p53 expression at $48 \mathrm{~h}$ after iodine-131 treatment (Fig. 6B).

\section{Discussion}

The extent of DNA damage induced by ionizing radiation depends on the type of radiation and the dose applied, as well as other factors. Higher radiation linear energy transfer results in greater complexity of the lesions, as well as more challenging repair of the induced lesions $(17,18)$. The results 
of the present study revealed that the inhibitory effect of iodine-131 on HTori-3 cell growth occurred via cell apoptosis and $\mathrm{G} 2 / \mathrm{M}$ phase arrest in a time- and dose-dependent manner, indicating that the cytotoxic effect of iodine-131 is associated with the irradiation time and dosage, as well as a number of other factors, including cell type or oxygenation status, which may require further study.

DNA damage induced by irradiation or drugs used for cancer chemotherapy may lead to apoptotic cell death (19). Irradiated HTori-3 cells presented a dose- and time-dependent increase in apoptosis. The Bcl-2 family is divided into proapoptotic proteins, including Bax, and antiapoptotic proteins, including Bcl-2 (10). Whether cell undergo apoptosis depends on the ratio of Bcl-2 to Bax, to a certain extent (11). Fas is known to be critical in the process of cell apoptosis induced by radiation damage and other DNA damage $(20,21)$. The intrinsic apoptotic pathway is dominated by the Bcl-2 family of proteins (22), while the cell-surface receptor, Fas (CD95/Apo-1) is a key component of the extrinsic death pathway $(20,21)$. The results of the present study (Fig. 4) identified that treatment of thyrocyte cells with iodine-131 resulted in decreased Bcl-2 and significantly increased Fas expression levels, indicating that the $\mathrm{Bcl}-2$ and Fas expression levels are involved in signal transmission in the process of cell apoptosis induced by $\beta$-ray radiation. In addition, the apoptosis of HTori-3 cells, which was induced by iodine-131, may occur through the death receptor pathway and the mitochondrial pathway. Friesen et al (1) also demonstrated that $\beta$ radiation-induced and -activated apoptosis pathways in leukemia cells by upregulating the expression levels of CD95 ligand and receptor, as well as activating caspases. In human breast cancer cells, apoptosis induced by strontium- 89 is also regulated by the decreased $\mathrm{Bcl}-2$ and increased Fas expression levels (2).

G1/S and G2/M cell cycle checkpoints are essential for the maintenance of genomic stability in response to DNA damage. An evident effect was observed on cell cycle phase distribution in the HTori-3 cell line due to the iodine-131 treatment, exhibiting a positive correlation with the concentration and time of iodine-131 treatment. A number of previous studies have also reported that the tumor cell cycle $\mathrm{G} 2 / \mathrm{M}$ retardation was induced by $\gamma$-ray radiation $(23,24)$. This process was also identified in the human breast carcinoma cell line, $\mathrm{MCF}-7$, when induced by ${ }^{89} \mathrm{Sr}$ and irradiated with $\beta$-rays (2). Eriksson et al (5) also demonstrated that HeLa Hep2 cells exhibited a transient $\mathrm{G} 2 / \mathrm{M}$ phase arrest following iodine-131 irradiation. GADD45, a DNA damage-inducible protein, has been identified to be critical in the $\mathrm{G} 2 / \mathrm{M}$ cell cycle checkpoint (25). GADD45 mRNA expression was found to be significantly increased following iodine-131 treatment of HTori-3 cells (Fig. 5). These results indicate that G2/M phase arrest mediated by GADD45 may be one of the underlying mechanisms of the growth inhibitory effect of iodine-131 on the HTori-3 cells.

The role and mechanism of the $\mathrm{p} 53$ tumor suppressor protein on the cellular response to radiation-induced DNA damage is well established. The p53 tumor suppressor gene is activated in the cellular response to various cellular stresses, including radiation-induced DNA damage, oncogene stimulation, hypoxia and nucleotide depletion (26). Activation of p53 results in cell growth arrest at G1 and/or G2 phase, DNA repair, senescence or apoptosis $(8,9)$. In the present study, to verify whether iodine-131 induced HTori-3 cell apoptosis in a p53-dependent pathway, the p53 mRNA and protein expression levels were evaluated following iodine-131 treatment. The results (Fig. 6) revealed that the mRNA and protein expression levels of p53 were not altered following iodine-131 exposure, indicating that apoptosis induced by iodine-131 is independent of p53.

In conclusion, the current study demonstrated that iodine-131 may induce apoptosis in HTori-3 cells by downregulating the expression levels of the Bcl-2 antiapoptotic protein and upregulating the mRNA and protein expression levels of Fas. Furthermore, iodine-131 treatment may upregulate the expression of GADD45 in the G2/M phase arrest in a p53-independent pathway. Therefore, the results of the present study suggest that cell apoptosis and cell cycle arrest in a p53-independent pathway may be the underlying mechanism in iodine-131 therapy of hyperthyroidism. Further investigation of the effects of $\beta$ radiation at the cellular level is required in order to enable its direct application in nuclear medicine.

\section{Acknowledgements}

The authors would like to thank Professor Peng Hou (Endocrinology Laboratory, The First Affiliated Hospital of Xi'an Jiaotong University College of Medicine, Xi'an, China) for providing useful advice. The project was supported by a grant from the National Natural Science Foundation of China (no. 81172598). The manuscript abstract was accepted as a meeting abstract by the Society of Nuclear Medicine and Molecular Imaging 2014 Annual Meeting (http://jnumedmtg. snmjournals.org/cgi/content/meeting_abstract $/ 55 / 1$ _

MeetingAbstracts/142) (28).

\section{References}

1. Friesen C, Lubatschofski A, Kotzerke J, Buchmann I, Reske SN and Debatin KM: Beta-irradiation used for systemic radioimmunotherapy induces apoptosis and activates apoptosis pathways in leukaemia cells. Eur J Nucl Med Mol Imaging 30: 1251-1261, 2003.

2. Wang C, Wang J, Jiang H, Zhu M, Chen B and Bao W: In vitro study on apoptosis induced by strontium- 89 in human breast carcinoma cell line. J Biomed Biotechnol 2011: 541487, 2011.

3. Sawka AM, Thephamongkhol K, Brouwers M, Thabane L, Browman G and Gerstein HC: Clinical review 170: A systematic review and metaanalysis of the effectiveness of radioactive iodine remnant ablation for well-differentiated thyroid cancer. J Clin Endocrinol Metab 89: 3668-3676, 2004.

4. Bogazzi F, Giovannetti C, Fessehatsion R, et al: Impact of lithium on efficacy of radioactive iodine therapy for Graves' disease: a cohort study on cure rate, time to cure, and frequency of increased serum thyroxine after antithyroid drug withdrawal. J Clin Endocrinol Metab 95: 201-208, 2010.

5. Eriksson D, Blomberg J, Lindgren T, Löfroth PO, et al: Iodine-131 induces mitotic catastrophes and activates apoptotic pathways in HeLa Hep2 cells. Cancer Biother Radiopharm 23: 541-549, 2008.

6. Marx K, Moka D, Schomäcker K, et al: Cell death induced by ${ }^{131} \mathrm{I}$ in a differentiated thyroid carcinoma cell line in vitro: necrosis or apoptosis? Nucl Med Commun 27: 353-358, 2006.

7. Reinhardt $\mathrm{HC}$ and Schumacher B: The $\mathrm{p} 53$ network: cellular and systemic DNA damage responses in aging and cancer. Trends Genet 28: 128-136, 2012.

8. Feng $\mathrm{Z}$ and Levine AJ: The regulation of energy metabolism and the IGF-1/mTOR pathways by the p53 protein. Trends Cell Biol 20: 427-434, 2010.

9. Jin S and Levine AJ: The p53 functional circuit. J Cell Sci 114: 4139-4140, 2001. 
10. Brunelle JK and Letai A: Control of mitochondrial apoptosis by the Bcl-2 family. J Cell Sci 122: 437-441, 2009.

11. Shi L, Chen J, Yang J,Pan T,Zhang S and Wang Z: MiR-21 protected human glioblastoma U87MG cells from chemotherapeutic drug temozolomide induced apoptosis by decreasing Bax/Bcl-2 ratio and caspase-3 activity. Brain Res 1352: 255-264, 2010.

12. Villa-Morales M, González-Gugel E, Shahbazi MN, Santos J and Fernández-Piqueras J: Modulation of the Fas-apoptosis-signalling pathway by functional polymorphisms at Fas, FasL and Fadd and their implication in T-cell lymphoblastic lymphoma susceptibility. Carcinogenesis 31: 2165-2171, 2010.

13. Ji J, Tian Y, Ji S, Zhang L, Zhu Y and Lu X: Ionizing radiation induces cell cycle G1 arrest and tumor suppressor gene P16, P21, P27 expression in keloid fibroblasts. Int J Radiat Oncol 87 (Suppl): S629, 2013

14. Niehrs C and Schäfer A: Active DNA demethylation by Gadd45 and DNA repair. Trends Cell Biol 22: 220-227, 2012.

15. Pilli T, Prasad KV, Jayarama S, Pacini F and Prabhakar BS: Potential utility and limitations of thyroid cancer cell lines as models for studying thyroid cancer. Thyroid 19: 1333-1342, 2009

16. Caudill CM, Zhu Z, Ciampi R, Stringer JR and Nikiforov YE: Dose-dependent generation of RET/PTC in human thyroid cells after in vitro exposure to $\gamma$-radiation: a model of carcinogenic chromosomal rearrangement induced by ionizing radiation. J Clin Endocrinol Metab 90: 2364-2369, 2005.

17. Moore S, Stanley FK and Goodarzi AA. The repair of environmentally relevant DNA double strand breaks caused by high linear energy transfer irradiation - no simple task. DNA Repair (Amst) 17: 64-73, 2014

18. Reisz JA, Bansal N, Qian J, Zhao W and Furdui CM. Effects of ionizing radiation on biological molecules - mechanisms of damage and emerging methods of detection. Antioxid Redox Signal 10: 260-292, 2014
19. Elmore S: Apoptosis: A review of programmed cell death. Toxicol Pathol 35: 495-516, 2007.

20. Villa-Morales $\mathbf{M}$ and Fernández-Piqueras J: Targeting the Fas/FasL signaling pathway in cancer therapy. Expert Opin Ther Targets 16: 85-101, 2012.

21. Koster R, Timmer-Bosscha H, Bischoff R, Gietema JA and de Jong S: Disruption of the MDM2-p53 interaction strongly potentiates p53-dependent apoptosis in cisplatin-resistant human testicular carcinoma cells via the Fas/FasL pathway. Cell Death Dis 2: e148, 2011.

22. Cory S and Adams JM: The Bcl2 family: regulators of the cellular life-or-death switch. Nat Rev Cancer 2: 647-656, 2002.

23. Sak A, Wurm R, Elo B, et al: Increased radiation-induced apoptosis and altered cell cycle progression of human lung cancer cell lines by antisense oligodeoxynucleotides targeting p53 and p21 WAF1/CIP1. Cancer Gene Ther 10: 926-934, 2003.

24. Fernet M, Mégnin-Chanet F, Hall J and Favaudon V: Control of the G2/M checkpoints after exposure to low doses of ionising radiation: implications for hyper-radiosensitivity. DNA Repair (Amst) 9: 48-57, 2010

25. Zimmermann M, Arachchige-Don AS, Donaldson MS, Dallapiazza RF, Cowan CE and Horne MC: Elevated cyclin G2 expression intersects with DNA damage checkpoint signaling and is required for a potent $\mathrm{G} 2 / \mathrm{M}$ checkpoint arrest response to doxorubicin. J Biol Chem 287: 22838-22853, 2012.

26. Fridman JS and Lowe SW: Control of apoptosis by p53. Oncogene 22: 9030-9040, 2003.

27. Zhang W, Gao R, Yu Y, Guo K, Liu Y and Yang A: Radioactive iodine-131 induces human thyrocyte cell line HTori 3 cell apoptosis and $\mathrm{G} 2 / \mathrm{M}$ arrest in a $\mathrm{p} 53$-independent pathway. $\mathrm{J}$ Nucl Med Meeting Abstracts 55: 142, 2014. 